Article

\title{
Antioxidant and Anti-Inflammatory Effects of White Mulberry (Morus alba L.) Fruits on Lipopolysaccharide-Stimulated RAW 264.7 Macrophages
}

\author{
Jae Sik Yu ${ }^{1, \dagger}$, Sung Ho Lim ${ }^{2,+}$, Seoung Rak Lee ${ }^{1}$, Chang-Ik Choi ${ }^{3, *}$ and Ki Hyun Kim ${ }^{1, *(1)}$ \\ 1 School of Pharmacy, Sungkyunkwan University, Suwon 16419, Korea; jsyu@bu.edu (J.S.Y.); \\ davidseoungrak@gmail.com (S.R.L.) \\ 2 BK21 FOUR Team and Integrated Research Institute for Drug Development, College of Pharmacy, \\ Dongguk University-Seoul, Goyang 10326, Korea; 93sho617@naver.com \\ 3 Integrated Research Institute for Drug Development, College of Pharmacy, Dongguk University-Seoul, \\ Goyang 10326, Korea \\ * Correspondence: cichoi@dongguk.edu (C.-I.C.); khkim83@skku.edu (K.H.K.); Tel.: +82-31-961-5230 (C.-I.C.); \\ +82-31-290-7700 (K.H.K.) \\ $+\quad$ These authors contributed equally to this work.
}

check for updates

Citation: Yu, J.S.; Lim, S.H.; Lee, S.R.; Choi, C.-I.; Kim, K.H. Antioxidant and Anti-Inflammatory Effects of White Mulberry (Morus alba L.) Fruits on Lipopolysaccharide-Stimulated RAW 264.7 Macrophages. Molecules 2021, 26, 920. https://doi.org/ $10.3390 /$ molecules 26040920

Academic Editor: Roberto Fabiani

Received: 12 January 2021

Accepted: 6 February 2021

Published: 9 February 2021

Publisher's Note: MDPI stays neutral with regard to jurisdictional claims in published maps and institutional affiliations.

Copyright: (c) 2021 by the authors. Licensee MDPI, Basel, Switzerland. This article is an open access article distributed under the terms and conditions of the Creative Commons Attribution (CC BY) license (https:/ / creativecommons.org/licenses/by/ $4.0 /)$.

\begin{abstract}
In this study, the protective effects of white mulberry (Morus alba) fruits on lipopolysaccharide (LPS)-stimulated RAW 264.7 macrophages were investigated. The ethanol (EtOH) extract of white mulberry fruits and its derived fractions contained adequate total phenolic and flavonoid contents, with good in vitro antioxidant radical scavenging activity. The extract and fractions also markedly inhibited ROS generation and antioxidant activity. After treatment with the EtOH extract and its fractions, LPS stimulation-induced elevated nitric oxide (NO) production was restored, which was primarily mediated by downregulation of inducible NO synthase expression. A total of 20 chemical constituents including flavonoids, steroids, and phenolics were identified in the fractions using ultra-high-performance liquid chromatography (UHPLC)-quadrupole time-of-flight (QTOF) high-resolution mass spectrometry (HRMS). These findings provide experimental evidence of the protective effects of white mulberry fruit extract against oxidative stress and inflammatory responses, suggesting their nutraceutical and pharmaceutical potential as natural antioxidant and anti-inflammatory agents.
\end{abstract}

Keywords: Morus alba L.; white mulberry fruits; antioxidant activity; anti-inflammatory activity; RAW 264.7 macrophages; UHPLC-QTOF-HRMS

\section{Introduction}

Inflammation, a major mechanism mediating innate and adaptive immunity, is a complex physiological response that protects the organism against foreign harmful stimuli such as pathogens, particles, and viruses. Inflammation is primarily classified as acute and chronic based on the underlying mechanisms and processes. Cellular and molecular processes of chronic inflammation are varied and depend on the organ involved and, thus, are closely associated with the development and deterioration of many chronic diseases including cardiovascular, neurological, pulmonary, metabolic, endocrine, and autoimmune disorders as well as cancer [1]. Following the initiation of inflammatory responses, immune system cells release pro-inflammatory cytokines such as tumor necrosis factor (TNF)- $\alpha$, interleukin (IL)-1 $\beta$, and IL-6, which induce the generation of reactive oxygen species (ROS) [2]. Persistent inflammation can cause cellular injury or hyperplasia following ROS overproduction by inflammatory cells. In addition, cellular antioxidant systems activate genes involved in DNA repair in response to ROS-induced DNA damage [3]. Similarly, excessive oxidative stress increases the levels of inflammatory cytokines and related molecules [4]. 
Macrophages have been found to play a key role in the host defense system, where they are involved in many immunologic functions including inflammatory modulation and removal of apoptotic cells. Macrophages are activated by exogenous mediators such as lipopolysaccharide (LPS), an endotoxin expressed in the cell walls of gram-negative bacteria. This phenomenon is considered the first step in the inflammatory process, and many studies of protective effects mediated by anti-inflammatory, immune-modulating, and antioxidant activities have been performed using LPS-treated macrophage cells $[5,6]$.

The white mulberry tree (Morus alba L.), a perennial plant belonging to the Moraceae family, is used in traditional medicine and widely known as an important food source for the silkworm [7]. Additionally, the mulberry tree has economic and ecological importance as it is known for its rapid growth and biomass production [8]. Its fruit is a multiple fruit with a sweet flavor, and it is extensively consumed in various forms including as tea, dessert, and beverages worldwide [7]. Specifically, the mulberry fruit, which is rich in beneficial nutrients, contain secondary metabolites that have pharmacological activities such as antidiabetic, antioxidant, anti-obesity, and anti-inflammatory effects [9].

Previous phytochemical studies of the mulberry fruit have identified secondary metabolites and phytochemicals including flavonoids, anthocyanins, carotenoids, triterpenoids, and phenols, serving as good sources of substances that mediate the various therapeutic effects mentioned. In the present study, we investigated the protective effects of white mulberry fruits on LPS-stimulated RAW 264.7 macrophages by determining cell viability and antioxidant and anti-inflammatory activities. Additionally, the extracts of white mulberry fruits were comprehensively analyzed to identify the active chemical constituents using ultra-high performance liquid chromatography (UHPLC)-quadrupole time-of-flight (QTOF)-high-resolution mass spectrometry (HRMS).

\section{Results}

\subsection{Total Phenolic and Flavonoid Contents}

The results showed that the ethanol (EtOH) extract of the white mulberry fruits and its derived fractions contained adequate total phenolic (from 102.0 to $204.3 \mathrm{mg}$ garlic acid equivalent (GAE)/g) and flavonoid (from 55.1 to $74.9 \mathrm{mg}$ catechin equivalent (CAE)/g) contents. Furthermore, the highest total phenolic content was found in the $n$-butanol $(\mathrm{BuOH})$ fraction $(204.3 \pm 4.7 \mathrm{mg} \mathrm{GAE} / \mathrm{g})$, the highest flavonoid content was in the ethyl acetate (EA) fraction (74.9 $\pm 4.7 \mathrm{mg} \mathrm{CAE} / \mathrm{g})$, while the hexane (HX) fraction exhibited the lowest values of both contents (Table 1 ).

Table 1. Total phenolic and flavonoid contents and antioxidant activities of EtOH extract and fractions of white mulberry fruits ${ }^{a}$.

\begin{tabular}{cccccc}
\hline & $\begin{array}{c}\text { Total Phenolic } \\
(\mathbf{m g} \text { GAE/g) }\end{array}$ & $\begin{array}{c}\text { Flavonoid } \\
(\mathbf{m g ~ C A E} / \mathbf{g})\end{array}$ & $\begin{array}{c}\text { DPPH } \\
(\mathbf{I C} \mathbf{5 0}, \boldsymbol{\mu g} / \mathbf{m L})\end{array}$ & $\begin{array}{c}\text { ABTS } \\
(\mathbf{I C} \mathbf{5 0}, \boldsymbol{\mu g} / \mathbf{m L})\end{array}$ & $\begin{array}{c}\text { FRAP } \\
(\mathbf{m m o l ~ F e}\end{array}$ \\
\hline EtOH extract & $173.1 \pm 3.9$ & $68.5 \pm 8.2$ & $>1000$ & $890.6 \pm 56.6$ & $0.770 \pm 0.019$ \\
EA fraction & $177.9 \pm 4.7$ & $74.9 \pm 8.6$ & $133.6 \pm 4.7$ & $216.6 \pm 28.8$ & $3.727 \pm 0.055$ \\
BuOH fraction & $204.3 \pm 4.7$ & $70.6 \pm 6.9$ & $471.1 \pm 35.3$ & $793.2 \pm 8.4$ & $1.259 \pm 0.026$ \\
HX fraction & $102.0 \pm 1.5$ & $55.1 \pm 9.6$ & $>1000$ & $>1000$ & $0.505 \pm 0.017$ \\
MC fraction & $124.7 \pm 0.6$ & $64.3 \pm 2.8$ & $475.0 \pm 18.4$ & $218.1 \pm 22.6$ & $1.649 \pm 0.023$ \\
\hline
\end{tabular}

${ }^{a}$ Data are means \pm standard deviation $(\mathrm{SD}, n=3)$. BuOH, butanol; EA, ethyl acetate; HX, hexane; MC, methylene chloride. DPPH, 2,2-diphenyl-1-picrylhydrazyl; ABTS, 2,2'-azino-bis(3-ethylbenzothiazoline-6-sulfonic acid); FRAP, ferric reducing antioxidant power; GAE, garlic acid equivalent; $\mathrm{CAE}$, catechin equivalent; $\mathrm{IC}_{50}$, half-maximal inhibitory concentration.

\subsection{Cell Viability}

Figure 1 shows the viability of RAW 264.7 cells treated with different concentrations of the EtOH extract and fractions of white mulberry fruits, which had no significant effect on cellular viability. There was an approximately $55 \%$ reduction in cell viability after pre-incubation of RAW 264.7 cells with LPS $2 \mu \mathrm{g} / \mathrm{mL}$, which was completely restored by treatment with $10 \mu \mathrm{M}$ quercetin used as a positive control. In addition, LPS-stimulated 
RAW 264.7 cells co-treated with white mulberry fruit extract and fractions showed dosedependent enhancement of viability (all $p<0.001$, Figure 1 ). The differences among the fractions were evaluated with multiple comparison analysis at the lowest concentration tested (5 $\mu \mathrm{g} / \mathrm{mL}$ for EA, HX and MC fractions; $10 \mu \mathrm{g} / \mathrm{mL}$ for $\mathrm{BuOH}$ fraction). The EA, HX and $\mathrm{MC}$ fractions exhibited better cell viability compared to $\mathrm{BuOH}$ fraction $(p<0.01)$.

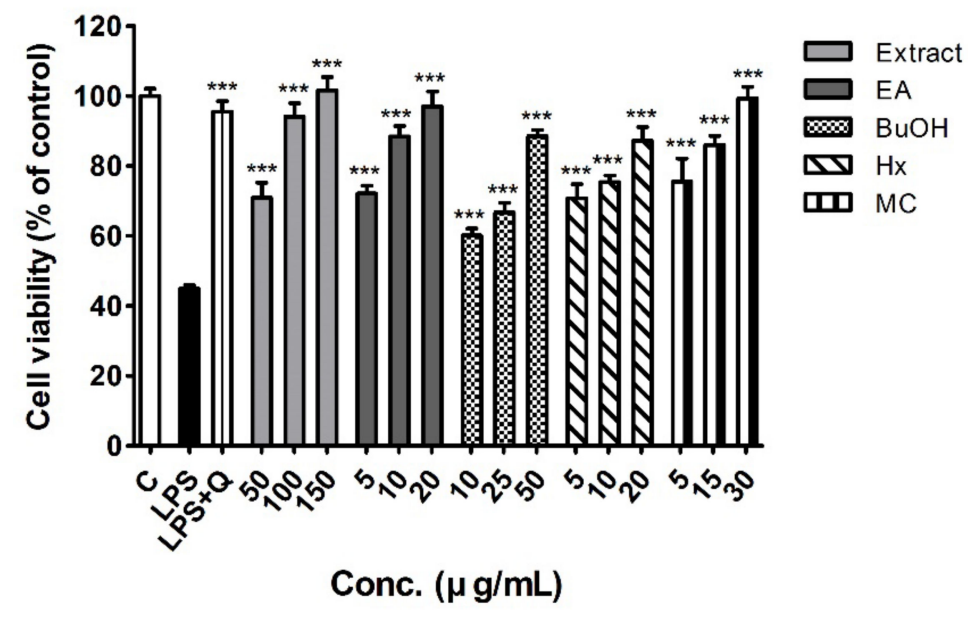

Figure 1. Effects of the EtOH extract and fractions of white mulberry fruits on cellular viability of RAW 264.7 macrophages stimulated with lipopolysaccharide (LPS, $2 \mu \mathrm{g} / \mathrm{mL}$ ). Data are expressed as means $\pm \mathrm{SD}(n=5){ }^{* * *} p<0.001$ vs. LPS treatment.

\subsection{Antioxidant Activity}

Comparative results of the in vitro antioxidant assays are presented in Table 1 . The EA, $\mathrm{BuOH}$, and $\mathrm{MC}$ fractions of the EtOH extract showed good 2,2-diphenyl-1-picrylhydrazyl (DPPH) radical scavenging activities, and the EA fraction exhibited the most potent activity (half-maximal inhibitory concentration $\left(\mathrm{IC}_{50}\right), 133.6 \pm 4.7 \mu \mathrm{g} / \mathrm{mL}$ ). The EtOH crude extract and $\mathrm{HX}$ fraction did not exhibit DPPH radical scavenging activity at the concentration range tested $\left(\mathrm{IC}_{50}>1000 \mu \mathrm{g} / \mathrm{mL}\right)$.

The extract and all fractions of white mulberry fruits except for the HX fraction, exhibited 2,2'-azino-bis(3-ethylbenzothiazoline-6-sulfonic acid) (ABTS) radical scavenging activities at the concentration range tested. The EA and $\mathrm{MC}$ fractions showed higher activity ( $\mathrm{IC}_{50}, 216.6 \pm 28.8$ and $218.1 \pm 22.6 \mu \mathrm{g} / \mathrm{mL}$, respectively) than the extract and other fractions. The ferric reducing antioxidant power (FRAP) values of the studied samples ranged from 0.505 to $3.727 \mathrm{mmol} \mathrm{Fe} \mathrm{m}^{2+} / \mathrm{g}$. Similar to the results of the DPPH and ABTS assay, those of the FRAP assay showed that the EA fraction $\left(3.727 \pm 0.055 \mathrm{mmol} \mathrm{Fe}^{2+} / \mathrm{g}\right)$ exhibited the highest value of all tested samples.

Intracellular ROS levels of LPS-stimulated RAW 264.7 macrophages were 5-fold higher than those of the control, whereas co-treatment with white mulberry fruit extract and fractions significantly inhibited LPS-induced ROS generation. Even at the lowest concentration, the EtOH extract and EA and MC fractions inhibited ROS production $(34.8 \%, 37.6 \%$, and $21.2 \%$ of LPS treatment levels, respectively) more than the positive control (quercetin 10 $\mu \mathrm{M}, 57.4 \%$ of LPS treatment levels) (Figure 2). After the multiple comparison analysis, EA and MC fractions showed significantly lower ROS generation than that in $\mathrm{BuOH}$ and $\mathrm{HX}$ fractions, respectively $(p<0.001)$.

The antioxidant activities of superoxide dismutase (SOD), catalase (CAT), and glutathione peroxidase (GPx) were also significantly enhanced by treatment with white mulberry fruits extract and fractions at the lowest studied concentrations, as described in Table 2. Significant differences between the fractions were observed only in the GPx activity; EA fraction exhibited better GPx activity than HX fraction $(p<0.01)$, and MC fraction had the highest GPx activity $(2.700 \pm 0.044 \mathrm{nmol} / \mathrm{min})$, reaching the significant levels compared to $\mathrm{BuOH}(p<0.05)$ and HX $(p<0.01)$ fraction. 


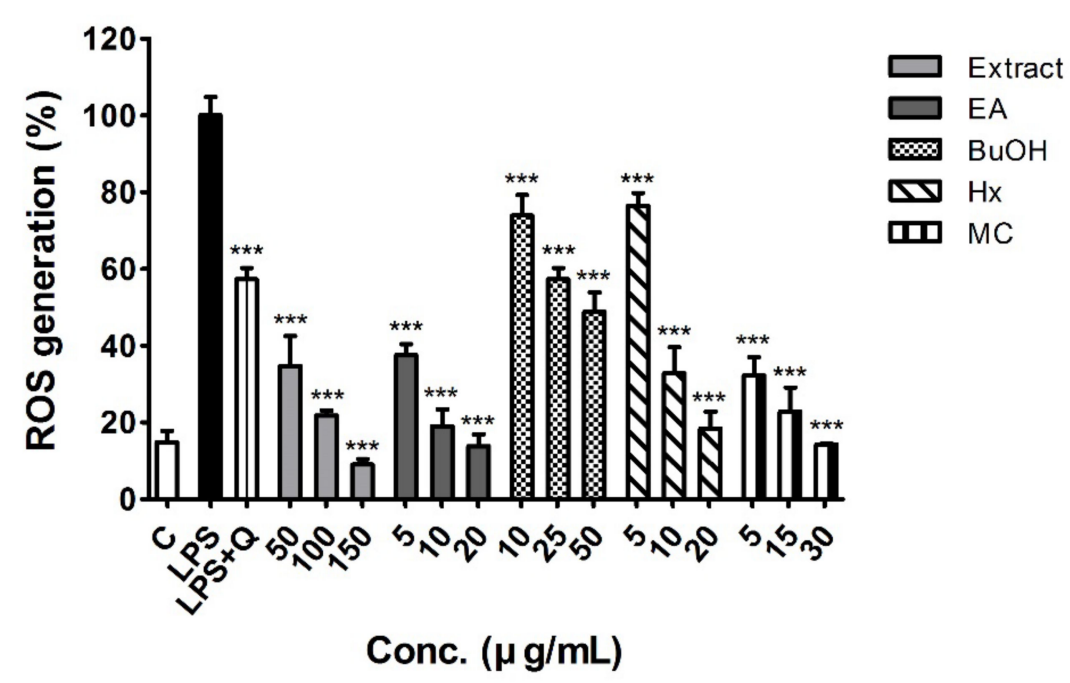

Figure 2. Effects of the EtOH extract and fractions of white mulberry fruits on reactive oxygen species (ROS) generation in LPS-stimulated RAW 264.7 macrophages. Data are expressed as means $\pm \mathrm{SD}(\mathrm{n}=5) .{ }^{* * *} p<0.001$ vs. LPS treatment.

Table 2. Antioxidant enzyme capacities of EtOH extract and fractions of white mulberry fruits in LPS-treated RAW 264.7 macrophages ${ }^{\text {a }}$.

\begin{tabular}{llll}
\hline & SOD $(\%$ of Control) & GPx (nmol/min) & CAT (unit/mL) \\
\hline Control $(0.5 \%$ DMSO) & 100.0 & $2.674 \pm 0.029$ & $0.147 \pm 0.007$ \\
LPS $2 \mu \mathrm{g} / \mathrm{mL}$ & $64.6 \pm 0.2^{\# \# \#}$ & $2.292 \pm 0.092^{\# \#}$ & $0.120 \pm 0.007^{\# \#}$ \\
LPS + Quercetin $(10 \mu \mathrm{M})$ & $93.7 \pm 5.1^{* * *}$ & $2.547 \pm 0.039^{* *}$ & $0.163 \pm 0.005^{* *}$ \\
LPS + EtOH Extract $(50 \mu \mathrm{g} / \mathrm{mL})$ & $78.7 \pm 3.2^{* *}$ & $2.776 \pm 0.025^{* * *}$ & $0.156 \pm 0.011^{*}$ \\
LPS + EA fraction $(5 \mu \mathrm{g} / \mathrm{mL})$ & $91.1 \pm 5.7^{* *}$ & $2.674 \pm 0.039^{* *}$ & $0.142 \pm 0.004^{*}$ \\
LPS + BuOH fraction $(10 \mu \mathrm{g} / \mathrm{mL})$ & $85.7 \pm 5.1^{* *}$ & $2.521 \pm 0.044^{* *}$ & $0.157 \pm 0.010^{* *}$ \\
LPS + HX fraction $(5 \mu \mathrm{g} / \mathrm{mL})$ & $85.6 \pm 2.0^{* * *}$ & $2.471 \pm 0.015^{*}$ & $0.162 \pm 0.011^{* *}$ \\
LPS + MC fraction $(5 \mu \mathrm{g} / \mathrm{mL})$ & $89.1 \pm 1.9^{* * *}$ & $2.700 \pm 0.044^{* *}$ & $0.146 \pm 0.012^{*}$ \\
\hline
\end{tabular}

a Data are means $\pm \mathrm{SD}(n=3)$. BuOH, butanol; EA, ethyl acetate; HX, hexane; MC, methylene chloride; SOD, superoxide dismutase; GPx, glutathione peroxidase; CAT, catalase. ${ }^{\# \#} p<0.01$ and ${ }^{\# \#} p<0.001$ vs. control; ${ }^{*} p<0.05,{ }^{* *} p<0.01$, and ${ }^{* * *} p<0.001$ vs. LPS treatment.

\subsection{Anti-Inflammatory Activity}

As shown in Figure 3A, nitric oxide (NO) levels were highly increased by LPS treatment of RAW 264.7 macrophages. The LPS-induced increase in NO production was significantly inhibited by quercetin $10 \mu \mathrm{M}$ (35.4\% of LPS treatment levels) as well as the white mulberry fruit extract and fractions in a concentration-dependent manner. Interestingly, the EtOH extract and MC and HX fractions exhibited potent inhibitory effects on NO production at the maximum tested concentrations $(20.2 \%, 29.9 \%$, and $32.8 \%$ of LPS treatment levels, respectively), which was slightly different from the results of the antioxidant activity analysis. In multiple comparison analysis, the significant differences were observed only between $\mathrm{EA}$ and $\mathrm{BuOH}$ fractions $(p<0.05)$. 

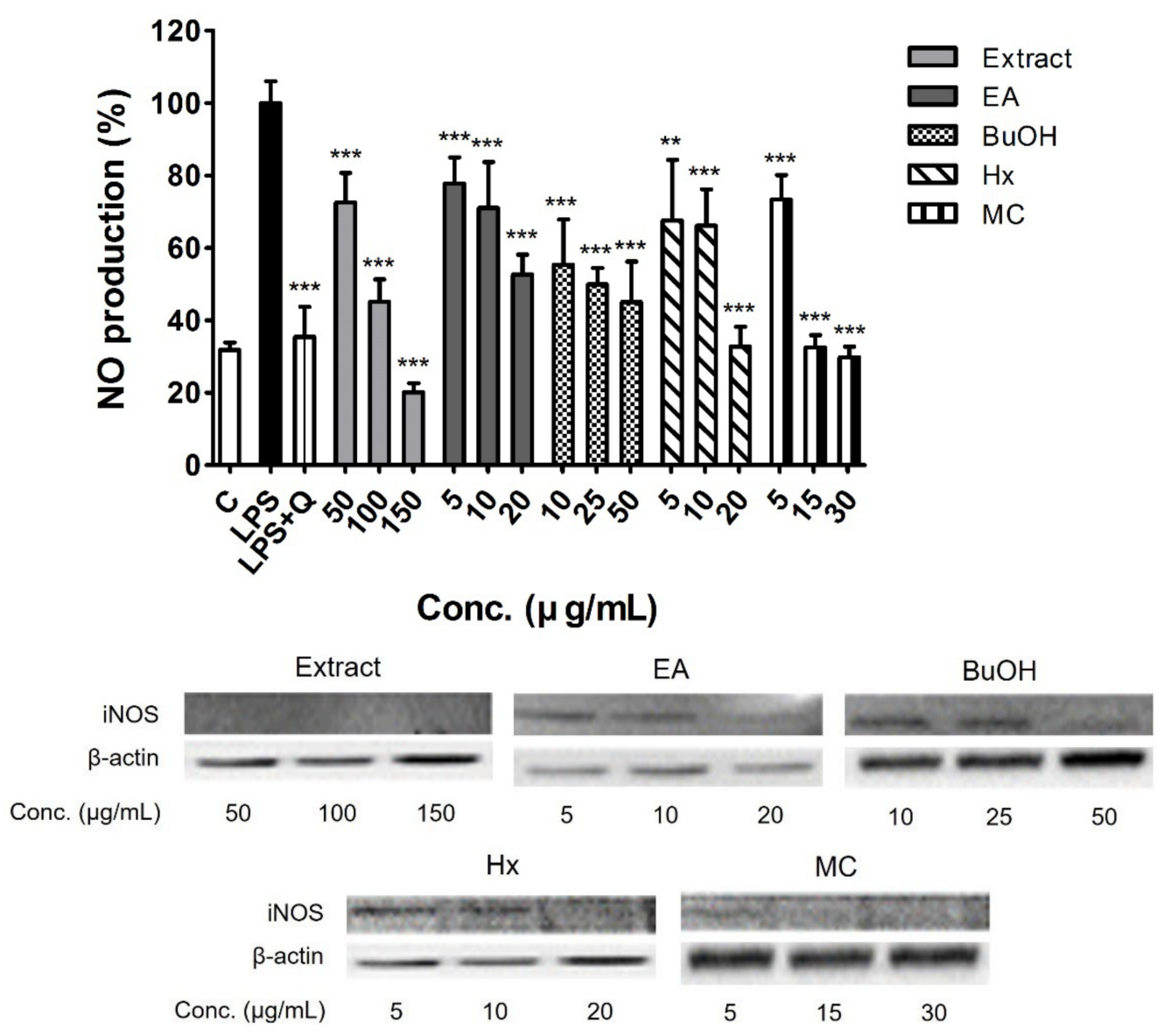

(A)

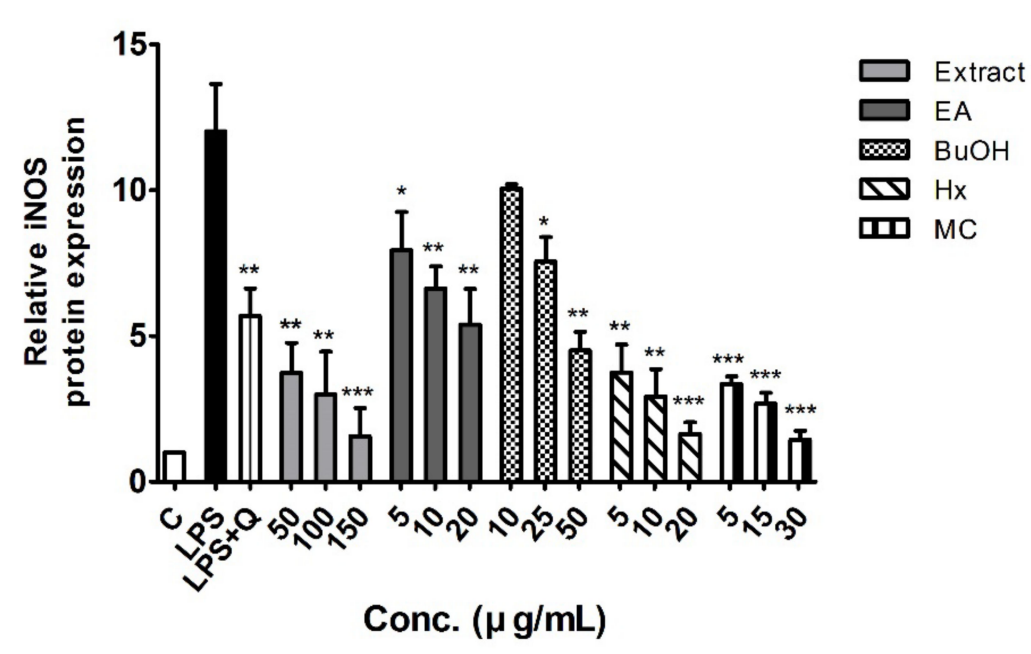

(B)

Figure 3. Effects of the EtOH extract and fractions of white mulberry fruits on NO production (A) and iNOS protein expression (B,C) in LPS-stimulated RAW 264.7 macrophages. Data are expressed as means \pm SD $(n=3)$. ${ }^{*} p<0.05$, ${ }^{* *} p<0.01$, and ${ }^{* * *} p<0.001$ vs. LPS treatment.

Figure $3 \mathrm{~B}, \mathrm{C}$ show the relative protein expression levels of inducible NO synthase (iNOS) in LPS-treated RAW 264.7 macrophages. Treatment with the white mulberry fruit extract and fractions resulted in lower iNOS levels than that observed with LPS-treatment only. Notably, the EtOH extract and HX and MC fractions showed a higher suppression of iNOS expression than the positive control treatment did at all studied concentration ranges. These findings were consistent with the results of multiple comparison analysis; both HX and $\mathrm{MC}$ fractions showed significantly lower iNOS expression than that in $\mathrm{EA}$ and $\mathrm{BuOH}$ fractions ( $p<0.01$ for EA vs. HX, $p<0.001$ for others). 


\subsection{Mass Spectral Identification and Qualitative Analysis of Extracts}

QTOF-MS is a widely used tool in the field of metabolomics that yields high mass accuracy and elucidates the elemental composition of compounds [10]. HRMS data yield valuable information that enables screening of the masses of secondary metabolites and, thus, are another powerful tool because compounds can be identified without using actual reference standards. The chemical constituents of the M. alba fruit extracts were qualitatively analyzed using UHPLC-QTOF-HRMS. In total, 20 chemical constituents were detected in the fractions of the crude extract (Table 3), and all the metabolites were characterized based on the MS data, which was interpreted based on currently available literature [11-16]. The exact mass of the reported compounds was compared with the obtained mass data to generate the parts per million (ppm) value. A parts per million value between the theoretical and measured exact mass of approximately $\pm 50 \mathrm{ppm}$ indicated the compound was a positive match [17]. Thus, lower parts per million values indicate a higher probability of the measure compound existing in the extract. The exact masses were calculated based on the possible proton and sodium adducts under positive ionization. The structures of these compound have been identified and characterized from M. alba in previously reported studies [11-16].

Table 3. Chemical constituents identified in the fractions of white mulberry fruits using ultra-high-performance liquid chromatography-quadrupole-time-of-flight-high-resolution mass spectrometry (UHPLC-QTOF-HRMS).

\begin{tabular}{|c|c|c|c|c|c|c|}
\hline Fractions & Compound & Formula & $\begin{array}{l}\text { Theoretical } \\
(\mathrm{m} / \mathrm{z})\end{array}$ & $\begin{array}{l}\text { Experimental } \\
(\mathrm{m} / \mathrm{z})\end{array}$ & Adduct & $\Delta(\mathrm{ppm})^{\mathrm{a}}$ \\
\hline \multirow[t]{3}{*}{ Hexane } & $\begin{array}{l}\text { Ar-Turmerone } \\
(2 S, 4 \mathrm{a} R, 4 \mathrm{~b} R, 6 \mathrm{a} R, 8 S, 10 \mathrm{a} R, \\
10 \mathrm{~b} R, 12 \mathrm{a} S)-8-(\text { Acetyloxy) }\end{array}$ & $\mathrm{C}_{15} \mathrm{H}_{20} \mathrm{O}$ & 217.1592 & 217.1585 & $\mathrm{M}+\mathrm{H}$ & -3.22 \\
\hline & $\begin{array}{l}\text { hexadecahydro- } \\
2,4 a, 4 b, 7,7,10 a-h e x a m e t h y l- \\
\text { 2-(3-oxobutyl)-1(2H)- } \\
\text { chrysenone }\end{array}$ & $\mathrm{C}_{30} \mathrm{H}_{48} \mathrm{O}_{4}$ & 473.3631 & 473.3621 & $\mathrm{M}+\mathrm{H}$ & -2.11 \\
\hline & Stigmasterol & $\mathrm{C}_{29} \mathrm{H}_{48} \mathrm{O}$ & 413.3783 & 413.3779 & $\mathrm{M}+\mathrm{H}$ & -9.68 \\
\hline \multirow[t]{6}{*}{$\begin{array}{l}\text { Methylene } \\
\text { chloride }\end{array}$} & Odisolane & $\mathrm{C}_{8} \mathrm{H}_{14} \mathrm{O}_{4}$ & 175.097 & 175.0979 & $\mathrm{M}+\mathrm{H}$ & 5.14 \\
\hline & \multirow{5}{*}{$\begin{array}{l}\text { 3-Benzofurancarbox } \\
\text { yaldehyde } \\
\text { Loliolide } \\
(R)-5 \text {-Hydroxypyrrolidin-2- } \\
\text { one } \\
\text { Methyl R-pyroglutamate } \\
\text { Indole }\end{array}$} & $\mathrm{C}_{9} \mathrm{H}_{6} \mathrm{O}_{2}$ & 147.0446 & 147.0437 & $\mathrm{M}+\mathrm{H}$ & -6.12 \\
\hline & & $\mathrm{C}_{11} \mathrm{H}_{16} \mathrm{O}_{3}$ & 197.1172 & 197.1178 & $\mathrm{M}+\mathrm{H}$ & 3.04 \\
\hline & & $\mathrm{C}_{4} \mathrm{H}_{7} \mathrm{NO}_{2}$ & 102.0547 & 102.0555 & $\mathrm{M}+\mathrm{H}$ & 7.84 \\
\hline & & $\mathrm{C}_{6} \mathrm{H}_{9} \mathrm{NO}_{3}$ & 144.0661 & 144.0655 & $\mathrm{M}+\mathrm{H}$ & -4.16 \\
\hline & & $\mathrm{C}_{8} \mathrm{H}_{7} \mathrm{~N}$ & 118.0657 & 118.0646 & $\mathrm{M}+\mathrm{H}$ & -9.32 \\
\hline \multirow[t]{7}{*}{ Ethyl acetate } & Quercetin & $\mathrm{C}_{15} \mathrm{H}_{10} \mathrm{O}_{7}$ & 303.0505 & 303.0499 & $\mathrm{M}+\mathrm{H}$ & -1.98 \\
\hline & Kaempferol & $\mathrm{C}_{15} \mathrm{H}_{10} \mathrm{O}_{6}$ & 287.0556 & 287.0549 & $\mathrm{M}+\mathrm{H}$ & -2.44 \\
\hline & Luteolin & $\mathrm{C}_{15} \mathrm{H}_{10} \mathrm{O}_{6}$ & 287.0556 & 287.0546 & $\mathrm{M}+\mathrm{H}$ & -3.48 \\
\hline & Astragalin & $\mathrm{C}_{21} \mathrm{H}_{20} \mathrm{O}_{11}$ & 449.1084 & 449.1082 & $\mathrm{M}+\mathrm{H}$ & -4.45 \\
\hline & Taxifolin & $\mathrm{C}_{15} \mathrm{H}_{12} \mathrm{O}_{7}$ & 305.0661 & 305.0656 & $\mathrm{M}+\mathrm{H}$ & -1.64 \\
\hline & Morrole A & $\mathrm{C}_{14} \mathrm{H}_{21} \mathrm{NO}_{5}$ & 284.1498 & 284.1489 & $\mathrm{M}+\mathrm{H}$ & -3.17 \\
\hline & Methyl chlorogenate & $\mathrm{C}_{17} \mathrm{H}_{20} \mathrm{O}_{9}$ & 369.1186 & 369.1181 & $\mathrm{M}+\mathrm{H}$ & -1.35 \\
\hline \multirow[t]{4}{*}{ n-Butanol } & \multirow{4}{*}{$\begin{array}{l}\text { Quercetin 3-O- } \beta \text {-glucoside } \\
\text { Kaempferol } \\
\text { 3-O- } \beta \text {-rutinoside } \\
\text { Rutin } \\
\text { Butyl L-pyroglutamate }\end{array}$} & $\mathrm{C}_{21} \mathrm{H}_{20} \mathrm{O}_{12}$ & 465.1033 & 465.1028 & $\mathrm{M}+\mathrm{H}$ & -1.08 \\
\hline & & $\mathrm{C}_{27} \mathrm{H}_{30} \mathrm{O}_{15}$ & 595.1663 & 595.1659 & $\mathrm{M}+\mathrm{H}$ & -6.72 \\
\hline & & $\mathrm{C}_{27} \mathrm{H}_{30} \mathrm{O}_{16}$ & 611.1612 & 611.1609 & $\mathrm{M}+\mathrm{H}$ & -4.91 \\
\hline & & $\mathrm{C}_{9} \mathrm{H}_{15} \mathrm{NO}_{3}$ & 186.113 & 186.1127 & $\mathrm{M}+\mathrm{H}$ & -1.61 \\
\hline
\end{tabular}

a Deviation of measured $m / z$ from calculated $m / z$ values for a pseudomolecular ion generated from the molecular formula. 


\section{Discussion}

The in vitro antioxidant assays performed in this study (DPPH, ABTS, and FRAP assays) are simple and most commonly used in the early screening of antioxidant properties of vegetable and fruit extracts and products [18]. DPPH is a highly colored and stable free radical, which in the presence of antioxidant substances is reduced to the non-radical 2,2diphenyl-1-picrylhydrazine, with a loss of its violet color [19]. The ABTS assay measures the capacity of an antioxidant to scavenge ABTS radicals $\left(\mathrm{ABTS}^{+}\right)$generated by reacting the parent compound with a strong oxidizing agent such as potassium persulfate. It can be used over a wide $\mathrm{pH}$ range in both aqueous and organic solvent systems [20]. The FRAP assay directly evaluates total antioxidant power, where the ferric-tripyridyltriazine $\left(\mathrm{Fe}^{3+}\right.$-TPTZ) complex is reduced to the ferrous form $\left(\mathrm{Fe}^{2+}\right)$ at low $\mathrm{pH}$, with an intense blue color [21]. In this study, the EtOH extract and fractions of white mulberry fruits exhibited appropriate DPPH and ABTS radical scavenging effects and FRAP values, which were especially high with the EA and MC fractions. On the contrary, the HX fraction showed the lowest antioxidant activity, with the $\mathrm{IC}_{50}$ values for DPPH and ABTS assays over the upper concentration limit tested in this study $\left(\mathrm{IC}_{50}>1000 \mu \mathrm{g} / \mathrm{mL}\right.$ ) (Table 1). These findings are very similar to the results of other previously published study [22]. The results suggest that the protective effect of white mulberry fruits against oxidative stress is primarily mediated by constituents of the EA and MC fractions.

Intracellular levels of free radicals can damage various cell constituents and activate specific signaling pathways, which both affect numerous cellular process linked to aging and the development of related diseases [23]. Overproduction of ROS and reduced antioxidant capacity can result in a redox imbalance, inducing the inflammatory response and oxidative stress eventually leading to the formation of various pathophysiological lesions [24]. Consistent with the results of previous studies [25-27], in this study, LPS increased ROS generation in stimulated RAW 264.7 macrophages (Figure 2). Co-treatment of LPS-stimulated RAW 264.7 macrophages with white mulberry fruit extract and fractions resulted in significant reductions in ROS levels. At the maximum concentrations used in this assay, all studied samples, except for the $\mathrm{BuOH}$ fraction, showed similar inhibition of ROS production to that in the control, which was not stimulated by LPS. Furthermore, the EA and MC fractions induced lower ROS levels than the positive control (quercetin $10 \mu \mathrm{M})$ at the lowest tested concentration, indicating the results were similar to those of the in vitro antioxidant assays (Figure 2).

Antioxidant enzymes such as SOD, GPx, and CAT stabilize or inactivate the detrimental effects of free radicals on cellular components. They also inhibit the oxidizing chain reaction to minimize free radical-induced cellular and molecular damages. By reducing cellular exposure to free radicals, antioxidant enzymes contribute to decreasing the risk for various associated health problems including the physiological manifestations of aging, cardiovascular diseases, diabetes, neurodegenerative diseases, and cancer [28]. SOD establishes the first-line defense system against superoxide radicals $\left(\mathrm{O}^{2-}\right)$ by catalyzing their breakdown to oxygen and $\mathrm{H}_{2} \mathrm{O}_{2}$ [29]. This ROS-scavenging process of SOD is only effective with the cooperative actions of GPx and CAT, during which $\mathrm{H}_{2} \mathrm{O}_{2}$ undergoes further degradation [30]. We found that the $\mathrm{EtOH}$ extract and all fractions of white mulberry fruits at the lowest concentrations used in this study simultaneously and significantly enhanced SOD, GPx, and CAT enzyme capacities, which were suppressed by LPS treatment (Table 2).

$\mathrm{NO}$ is a free radical widely distributed in the body that regulates various biological functions including vasodilation, smooth muscle contraction, neuronal signaling, platelet aggregation inhibition, immunological regulation, and inflammatory responses [31,32]. LPS-induced activation of macrophages leads to iNOS expression, resulting in increased NO production [33]. Excessive NO levels have been implicated in cell death, inflammatory responses, and the pathogenesis of several disease states [34,35]. In this study, white mulberry fruit extract and fractions significantly inhibited the production of nitrites in LPS-stimulated macrophage cells, which protected cell viability (Figures 1 and 3A). We also confirmed that protein expression level of iNOS was lower after treatment with 
white mulberry fruit samples than that before treatment (Figure 3B,C). This observation indicates that the reduction of NO levels in LPS-stimulated RAW 264.7 macrophages treated with white mulberry fruit extract was primarily mediated by downregulation of iNOS expression. To the best of our knowledge, this is the first study to investigate the anti-inflammatory activity and its underlying mechanism of the fractions of $M$. alba fruit.

Table 3 shows the various chemical constituents we identified from the white mulberry fruit fractions using UHPLC-QTOF-HRMS analysis. From the multiple comparison analyses, superior antioxidant and anti-inflammatory activities in EA and MC fractions were confirmed. Most compounds from the EA fraction, which has the highest total flavonoid content (Table 1), were flavonoids or their derivatives. The constituents identified in this study (quercetin, kaempferol, luteolin, astragalin, and taxifolin) have shown various biological health-promoting effects including antioxidant and anti-inflammatory activities mediated through different molecular mechanisms [36-40]. On the other hand, constituents with various chemical structures were found in the MC fraction. Indole is an aromatic heterocyclic compound commonly distributed in nature. Many well-known indole derivatives have been developed as pharmaceutical agents such as nonsteroidal antiinflammatory drugs (indomethacin and etodolac), antimigraine agents (sumatriptan and naratriptan), and a non-selective $\beta$-blocker (pindolol). In addition, numerous biological activities including antioxidant, anti-inflammatory, analgesic, antimicrobial, antidiabetic, antidepressant, and anticancer have been reported for compounds with an indole nucleus [41]. Loliolide is a monoterpenoid active ingredient found in green algae that exhibits antioxidant, antiviral, anti-inflammatory, anticancer, antimelanogenic, and antiapoptotic properties [42-46]. Odisolane was recently isolated as a novel oxolane derivative from $70 \%$ aqueous methanol extracts of $M$. alba fruits [47]. Odisolane significantly inhibited angiogenesis in human umbilical vein vascular endothelial cells, a pathological process that is closely related to chronic inflammation and oxidative stress [12,48]. It was not possible to determine the specific individual effects of the identified compounds because other minor components were also present in the extract and fractions; however, the antioxidant and anti-inflammatory activities of white mulberry fruit could be partially attributed to the complex effects of these active constituents.

The limitation of this study is that the signaling pathway associated with anti-inflammatory effects of white mulberry fruits were not fully identified. Nuclear factor (NF)$\kappa \mathrm{B}$ induces pro-inflammatory cytokines, chemokines, and adhesion molecules that are essential for both innate and adaptive immune responses [49]. NF- $\mathrm{KB}$ has been known to play a role in the expression of iNOS and another well-known inflammatory marker, COX-2. Consequently, we also evaluated the effects of white mulberry fruit extract and fractions on the NF- $\mathrm{kB}$ signaling pathway and COX-2 expression. However, there was no significant change in NF- $\mathrm{KB}$ p 65 or COX-2 protein expression following treatment with white mulberry fruit extract and fractions (data not shown), although they are overexpressed in RAW 264.7 macrophages after LPS stimulation. Several studies have reported that the expression of iNOS and COX-2 is also affected by mitogen-activated protein kinase (MAPK), which is involved in the regulation of cell growth, differentiation, and apoptosis [47,50-52]. Therefore, further investigations are needed to determine the possible inactivation of the MAPK pathway by white mulberry fruit.

\section{Materials and Methods}

\subsection{Materials}

$\left( \pm\right.$ )-Catechin, copper (II) chloride, $2^{\prime}, 7^{\prime}$-dichlor- ofluorescin diacetate (DCF-DA), dimethyl sulfoxide (DMSO), ethylenediaminetetraacetic acid (EDTA), Folin-Ciocalteu's phenol reagent, gallic acid, glutathione (GSH), GSH reductase, hydrogen peroxide, 3-(4,5dimethylthiazol-2-yl)-2,5-diphenyltetrazolium bromide (MTT), LPS, nicotinamide adenine dinucleotide phosphate (NADPH), nitroblue tetrazolium (NBT), phosphate-buffered saline (PBS), quercetin, xanthine, and xanthine oxidase were purchased from Sigma-Aldrich (St. Louis, MO, USA). 
The Griess reagent system kit was purchased from Promega (Madison, WI, USA). Dulbecco's modified Eagle's medium (DMEM), fetal bovine serum (FBS), and penicillin/ streptomycin were purchased from Thermo Fisher Scientific (Waltham, MA, USA). Primary antibodies for iNOS and $\beta$-actin were purchased from Cell Signaling Technology (Danvers, MA, USA). Goat anti-rabbit IgG secondary antibody and other chemical reagents were purchased from Merck Millipore (Burlington, MA, USA).

\subsection{Plant Material, Extraction, and Preparation of Fractions}

Mulberry fruits (M. alba) were acquired from the Kyungdong Market (Woori Herb), Seoul, Korea, in January 2014. The material was verified by one of the authors (K.H.K.), and a voucher specimen (MA 1414) was deposited in the herbarium of the School of Pharmacy, Sungkyunkwan University, Suwon, Korea. The M. alba fruits $(0.9 \mathrm{~kg})$ were dried in a hot air oven at $60{ }^{\circ} \mathrm{C}$ and the dried materials were extracted with $70 \%$ aqueous $\mathrm{EtOH}$ and filtered using Whatman filter paper No. 42 three times at room temperature. The filtrate was evaporated in vacuo to obtain the crude EtOH extract (140 g). The extract was dissolved in deionized water and then solvent-partitioned with $800 \mathrm{~mL}$ each of $\mathrm{HX}, \mathrm{MC}, \mathrm{EA}$, and $\mathrm{BuOH}$ three times, yielding 2.8 8.5, 3.3, and $13.9 \mathrm{~g}$ of the fractions, respectively. Concentrated extracts and fractions were subsequently lyophilized and stored at $-20^{\circ} \mathrm{C}$ prior to analysis.

\subsection{Determination of Total Phenolic Content}

The total phenolic content was determined using the Folin-Ciocalteu method with some modifications [53]. Each sample $(100 \mu \mathrm{L})$ was mixed with $200 \mu \mathrm{L}$ Folin-Ciocalteu

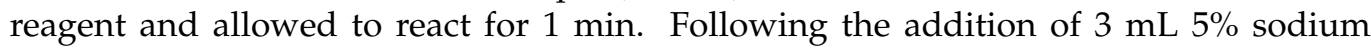
carbonate $\left(\mathrm{Na}_{2} \mathrm{CO}_{3}\right)$, the mixtures were incubated for $60 \mathrm{~min}$ at room temperature in the dark. The absorbance was measured at a wavelength of $725 \mathrm{~nm}$ using a microplate spectrophotometer (xMark, Bio-Rad, Hercules, CA, USA). Gallic acid was used as the standard, and the total phenolic content were determined from calibration curves for gallic acid $\left(y=2.4652 x+0.008, r^{2}=0.9998\right)$. Results were expressed as milligrams of gallic acid equivalents per gram of sample (mg GAE/g).

\subsection{Determination of Flavonoid Content}

The flavonoid content was determined using the aluminum chloride $\left(\mathrm{AlCl}_{3}\right)$ method with some modifications [54]. Each sample $(100 \mu \mathrm{L})$ was mixed with $150 \mu \mathrm{L}$ sodium nitrite $\left(\mathrm{NaNO}_{2}\right)$ and allowed to react for $5 \mathrm{~min}$. Then, $300 \mu \mathrm{L} 10 \% \mathrm{AlCl}_{3}$ solution and $1 \mathrm{~mL}$ $1 \mathrm{M}$ sodium hydroxide were added, and the absorbance was measured at a wavelength of $510 \mathrm{~nm}$ using a microplate spectrophotometer at $510 \mathrm{~nm}$. ( \pm )-Catechin was used as the standard, and the flavonoid content were determined from calibration curves for $( \pm)$ catechin $\left(y=0.9472 x+0.0011, r^{2}=0.9964\right)$. Results were expressed as milligrams of catechin equivalents per gram of sample (mg CAE/g).

\subsection{Cell Culture}

Murine RAW 264.7 macrophage cells were cultured in DMEM containing $4 \mathrm{mM}$ L-glutamine, $4.5 \mathrm{~g} / \mathrm{L}$ glucose, and sodium pyruvate supplemented with $10 \% \mathrm{FBS}$ and $1 \%$ penicillin/streptomycin. Cells were maintained in a humidified atmosphere with $5 \%$ carbon dioxide $\left(\mathrm{CO}_{2}\right)$ at $37^{\circ} \mathrm{C}$.

\subsection{Cell Viability}

Cell viability was assessed using the MTT assay with some modifications [55-59]. Briefly, cell were seeded in 96-well plates $\left(2 \times 10^{4}\right.$ cell/well) and treated with $0.5 \%$ DMSO (control), $10 \mu \mathrm{M}$ quercetin (positive control), or different concentrations of the crude extract of white mulberry fruit $(50-150 \mu \mathrm{g} / \mathrm{mL})$ and the EA $(5-20 \mu \mathrm{g} / \mathrm{mL}), \mathrm{BuOH}(10-50 \mu \mathrm{g} / \mathrm{mL})$, $\mathrm{HX},(5-20 \mu \mathrm{g} / \mathrm{mL})$, and MC (5-30 $\mathrm{g} / \mathrm{mL})$ fractions in the absence or presence of LPS $(2 \mu \mathrm{g} / \mathrm{mL}$ in PBS) for $24 \mathrm{~h}$. Following treatment, $20 \mu \mathrm{L}$ MTT solution $(5 \mathrm{mg} / \mathrm{mL}$ in PBS) was added to each well, and the plates were incubated at $37{ }^{\circ} \mathrm{C}$ in an atmosphere of $5 \%$ 
$\mathrm{CO}_{2}$ for $2 \mathrm{~h}$. Then, the supernatant was removed, and $100 \mu \mathrm{L}$ DMSO was added to each well to dissolve any formazan crystals that developed. The absorbance of each well was measured at $570 \mathrm{~nm}$ using a microplate spectrophotometer.

\subsection{Antioxidant Activity}

\subsubsection{DPPH Radical Scavenging Assay}

The DPPH radical scavenging activity was determined using the method of Blois [60] with some modifications. Briefly, $50 \mu \mathrm{L} 0.2 \mathrm{mM}$ DPPH solution was added to the same volume of each sample at a concentration range of $10-1000 \mu \mathrm{g} / \mathrm{mL}$ and incubated at room temperature for $15 \mathrm{~min}$ in the dark. The absorbance was measured using a microplate spectrophotometer at $517 \mathrm{~nm}$. The scavenging activity was calculated as follows: DPPH scavenging activity $(\%)=\left(\left(\mathrm{A}_{0}-\mathrm{A}_{\mathrm{c}}\right) / \mathrm{A}_{0}\right) \times 100$ (where, $\mathrm{A}_{0}$ and $\mathrm{A}_{\mathrm{c}}$ are the absorbance of the control and sample, respectively).

\subsubsection{ABTS Radical Scavenging Assay}

The ABTS radical scavenging activity was determined using the method of Arts et al. [61] using ABTS with some modifications. Briefly, $7 \mathrm{mM}$ ABTS and $2.45 \mathrm{mM}$ potassium persulfate were mixed (1:1) and incubated for at room temperature $24 \mathrm{~h}$ in the dark. The ABTS solution was diluted in $100 \%$ methanol to obtain an absorbance of $0.70 \pm 0.02$ at $734 \mathrm{~nm}$. Then, $50 \mu \mathrm{L}$ diluted ABTS solution was added to the same volume of each sample at a concentration range of $10-1000 \mu \mathrm{g} / \mathrm{mL}$ and incubated for at room temperature $5 \mathrm{~min}$ in the dark. The absorbance was measured using a microplate spectrophotometer at $734 \mathrm{~nm}$. The scavenging activity was calculated as follows: ABTS scavenging activity (\%) $=\left(\left(\mathrm{A}_{0}-\mathrm{A}_{\mathrm{c}}\right) / \mathrm{A}_{0}\right) \times 100$ (where $\mathrm{A}_{0}$ and $\mathrm{A}_{\mathrm{c}}$ are the absorbance of the control and sample, respectively).

\subsubsection{FRAP Assay}

The FRAP assay was performed using the method of Benzie and Strain [21] with some modifications. The FRAP reagent was prepared by mixing $300 \mathrm{mM}$ acetate buffer ( $\mathrm{pH}$ 3.6), $10 \mathrm{mM} \mathrm{2,4,6-tris(2-pyridyl)-s-triazine,} \mathrm{and} 20 \mathrm{mM}$ ferric chloride $\left(\mathrm{FeCl}_{3} \cdot 6 \mathrm{H}_{2} \mathrm{O}\right)$ at a 10:1:1 ratio. Then, $175 \mu \mathrm{L}$ FRAP reagent was added to $25 \mu \mathrm{L}$ of each test sample at a concentration of $1000 \mu \mathrm{g} / \mathrm{mL}$ and incubated at $37{ }^{\circ} \mathrm{C}$ for $4 \mathrm{~min}$. Ferrous sulfate $\left(\mathrm{FeSO}_{4} \cdot 7 \mathrm{H}_{2} \mathrm{O}\right)$ was used as the standard, and the absorbance was measured at a wavelength of $593 \mathrm{~nm}$ using a microplate spectrophotometer. The results are expressed as millimoles (mmol) of $\mathrm{FeSO}_{4} \cdot 7 \mathrm{H}_{2} \mathrm{O}$ equivalents per gram of sample (mmol Fe $\left.{ }^{2+} / \mathrm{g}\right)$.

\subsubsection{Measurement of Intracellular ROS Levels}

Intracellular ROS levels were measured using the DCF-DA assay as described by Sittisart and Chitsomboon [62]. Cell were seeded in 96-well plates $\left(2 \times 10^{4}\right.$ cell/well), treated with the positive control or different concentrations of crude extract and fractions of white mulberry fruits for $2 \mathrm{~h}$, and then incubated with LPS for $20 \mathrm{~h}$. Then, the supernatant was discarded, and $20 \mu \mathrm{M}$ DCF-DA in serum-free DMEM was added, followed by further incubation at $37^{\circ} \mathrm{C}$ for $30 \mathrm{~min}$, protected from light. The supernatant was removed and washed with PBS twice, and then $100 \mu \mathrm{L}$ PBS was added to each well. The fluorescence intensity was detected at excitation and emission wavelengths of 485 and $535 \mathrm{~nm}$, respectively, using a multi-mode microplate reader (SpectraMax M3, Molecular Devices, San Jose, CA, USA).

\subsubsection{Antioxidant Enzyme Capacity Assays}

The antioxidant enzyme capacity was assayed in accordance with the methods previously described by Lee et al. [30]. Briefly, RAW 264.7 cells were seeded in 24-well plates $\left(2 \times 10^{5}\right.$ cell/well $)$, treated with the positive control or white mulberry fruits extract and fractions for $2 \mathrm{~h}$, and then they were incubated with LPS for $20 \mathrm{~h}$. The culture medium 
was removed, and the cells were washed twice and then scraped with $1 \mathrm{~mL}$ PBS. Cell suspension were centrifuged at $14,000 \mathrm{rpm}$ at $4{ }^{\circ} \mathrm{C}$ for $5 \mathrm{~min}$.

For the determination of SOD activity, cell homogenates were prepared by homogenizing cell suspensions with $0.05 \mathrm{M}$ sodium carbonate buffer ( $\mathrm{pH}$ 10.2). The final reaction mixture consisted of $50 \mu \mathrm{L}$ cell homogenate and $0.05 \mathrm{M}$ sodium carbonate buffer containing $3 \mathrm{mM}$ xanthine, $0.75 \mathrm{mM}$ NBT, $3 \mathrm{mM}$ EDTA, and $1.5 \mathrm{mg} / \mathrm{mL}$ bovine serum bovine albumin (BSA). The reaction was initiated by adding $50 \mu \mathrm{L}$ xanthine oxidase $(0.1 \mathrm{mg} / \mathrm{mL})$ and incubating at room temperature for $30 \mathrm{~min}$, and then it was stopped by adding $6 \mathrm{mM}$ copper (II) chloride and centrifuging at $1500 \mathrm{rpm}$ for $10 \mathrm{~min}$. The absorbance of blue formazan in the supernatant was determined at a wavelength of $560 \mathrm{~nm}$.

The assay mixture for determining GPx activity contained $0.1 \mathrm{M}$ phosphate buffer (pH 7.0), 1 mM EDTA, $1.5 \mathrm{mM}$ NADPH, $1 \mathrm{mM}$ sodium azide, 1 unit of GSH reductase, $10 \mathrm{mM} \mathrm{GSH}$, and $100 \mu \mathrm{L}$ cell lysates. This mixture was incubated at $37^{\circ} \mathrm{C}$ for $10 \mathrm{~min}$, and then hydrogen peroxide $\left(\mathrm{H}_{2} \mathrm{O}_{2}\right)$ was added to each sample at a final concentration of $1 \mathrm{mM}$, followed by the measurement of activity at a wavelength of $340 \mathrm{~nm}$.

The assay mixture for CAT activity contained $12 \mu \mathrm{L} 3 \% \mathrm{H}_{2} \mathrm{O}_{2}$ and $100 \mu \mathrm{L}$ cell lysates in $50 \mathrm{mM}$ phosphate buffer (pH 7.0), and samples were incubated at $37^{\circ} \mathrm{C}$ for $2 \mathrm{~min}$. The absorbance of the samples was measured for $5 \mathrm{~min}$ at a wavelength of $240 \mathrm{~nm}$. The variation in absorbance is proportional to the breakdown of $\mathrm{H}_{2} \mathrm{O}_{2}$.

\subsection{Anti-Inflammatory Activity}

\subsubsection{Measurement of Intracellular NO levels}

The concentration of nitrite, a stable oxidized product of $\mathrm{NO}$, in the cell culture medium was determined using a Griess reagent system kit (Promega). Cells were seeded in 96-well plates $\left(2 \times 10^{4}\right.$ cell/well) and treated with the positive control or different concentrations of white mulberry fruits crude extract and fractions for $2 \mathrm{~h}$, followed by LPS for $24 \mathrm{~h}$. Then, $50 \mu \mathrm{L}$ samples of the supernatant from the treated culture medium was mixed with $50 \mu \mathrm{L} 1 \%$ sulfanilamide in $5 \%$ phosphoric acid and incubated at room temperature for $10 \mathrm{~min}$, protected from light. Then, $50 \mu \mathrm{L} 0.1 \% \mathrm{~N}$-1-napthylethylenediamine dihydrochloride in water was added, followed by incubation at room temperature for $10 \mathrm{~min}$, protected from light. The absorbance was measured at a wavelength of $540 \mathrm{~nm}$ using a microplate spectrophotometer. The $\mathrm{NO}$ level of each experimental sample was calculated using a $\mathrm{NaNO}_{2}(0-100 \mu \mathrm{M})$ standard curve.

\subsubsection{Measurement of iNOS Protein Expression}

For Western blot analysis, cells were seeded in 12 -well plates $\left(5 \times 10^{5}\right.$ cells/well) and pre-incubated for $2 \mathrm{~h}$ with the positive control and different concentrations of the crude extract and each fraction. After LPS stimulation at $37^{\circ} \mathrm{C}$ for $20 \mathrm{~h}$ in a humidified atmosphere of $5 \% \mathrm{CO}_{2}$, cells were washed with PBS, homogenized with lysis buffer containing a protease inhibitor cocktail, and centrifuged at $14,000 \mathrm{rpm}\left(4^{\circ} \mathrm{C}, 20 \mathrm{~min}\right)$. Each supernatant sample containing an equal total protein amount $(20 \mu \mathrm{g})$ was loaded for separation using $10 \%$ sodium dodecyl sulfate-polyacrylamide gel electrophoresis and then transferred onto a polyvinylidene difluoride membrane.

After blocking with $5 \%$ skim milk for $1 \mathrm{~h}$, the membrane was incubated with a primary antibody against iNOS (1:1000 dilution in $5 \%$ BSA) at $4{ }^{\circ} \mathrm{C}$ overnight, followed by a horseradish peroxidase-conjugated secondary antibody (1:2000 dilution in 5\% skim milk) at room temperature for $1 \mathrm{~h}$. The membrane was washed, and immunoreactive bands were detected using the ChemiDoc imaging system with an enhanced chemiluminescence solution kit (Bio-Rad).

\subsection{Chemical Profiling and Qualitative UHPLC-QTOF-MS Analysis}

Extracts of white mulberry fruits were chemically profiled using an Agilent 1290 Infinity II HPLC instrument (Foster City, CA, USA) coupled to a G6545B Q-TOF mass spectrometer (Agilent Technologies). HX, MC, EA, and $n$ - $\mathrm{BuOH}$ soluble fractions were 
dissolved in the respective extraction solvents and filtered through $0.45-\mu \mathrm{m}$ filters before injection. The identified compounds were separated using an Agilent EclipsePlus C18 column $(2.1 \mathrm{~mm} \times 50 \mathrm{~mm}, 1.8 \mu \mathrm{m}$; flow rate $0.3 \mathrm{~mL} / \mathrm{min})$ maintained at $20^{\circ} \mathrm{C}$. The mobile phrase consisted of $0.1 \%$ formic acid in water (solvent $\mathrm{A}$ ) and $100 \%$ acetonitrile (solvent $\mathrm{B})$. The gradient elution was performed on the following schedule: $90 \% \mathrm{~A} \rightarrow 100 \% \mathrm{~B}$ (0-10 $\mathrm{min}), 100 \% \mathrm{~B}(11-16 \mathrm{~min})$, and 90\% A (16-20 $\mathrm{min})$ for equilibration before the next injection. The samples were monitored at 210 and $254 \mathrm{~nm}$ during the chromatographic run. The mass spectral analysis was performed using the MassHunter software (Agilent, Foster City, CA, USA), and the mass spectrometer conditions were as follows: ionization mode, electrospray ionization (ESI (+)); MS scan range, $m / z$ 100-1700; nebulizer gas $\left(\mathrm{N}_{2}\right)$ pressure, $35 \mathrm{psi}$; dry gas $\left(\mathrm{N}_{2}\right)$ flow rate, $8 \mathrm{~L} / \mathrm{min}$; drying gas temperature, $225^{\circ} \mathrm{C}$; sheath gas temperature, $320^{\circ} \mathrm{C}$; capillary voltage, $3.5 \mathrm{kV}$; fragmentor voltage, $100 \mathrm{~V}$; collision energy, $3.0 \mathrm{eV}$ [63]. The exact mass of some of the organic compounds identified from the mass spectral data was compared with theoretical values from previous studies [11-16]. The significance of the obtained data was confirmed by the results calculated from the obtained and theoretical data. The accuracy was reported as change $(\Delta$, parts per million $(\mathrm{ppm}))$ and was calculated using the following equation,

$$
\frac{\left(\text { mass }_{\text {exp }}-\text { mass }_{\text {calc }}\right)}{\text { mass }_{\exp }} \times 10^{6}
$$

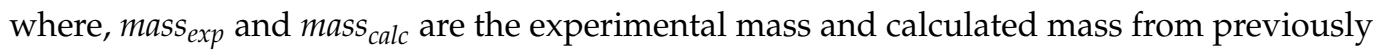
published molecular formulas, respectively [17].

\subsection{Statistical Analysis}

All experiments were replicated three or five times, and assay results are expressed as the means $\pm \mathrm{SD}$. The $\mathrm{IC}_{50}$ value of the $\mathrm{DPPH}$ and ABTS radical scavenging assays was defined as the concentration of sample scavenging $50 \%$ of the free radicals. The significance of the difference in mean values between each mulberry fruit sample and control or LPS treatment sample were analyzed using the Student's $t$-test, and the difference in mean values among mulberry fruit fractions at the lowest concentration $(5 \mu \mathrm{g} / \mathrm{mL}$ for EA, HX and $\mathrm{MC}$ fractions; $10 \mu \mathrm{g} / \mathrm{mL}$ for $\mathrm{BuOH}$ fraction) were analyzed using the one-way analysis of variance (ANOVA) with post-hoc Tukey multiple comparison test. $p$-values $<0.05$ were considered statistically significant.

\section{Conclusions}

In conclusion, we demonstrated that white mulberry fruits contain adequate amounts of total phenolics and flavonoids and exhibited beneficial antioxidant and anti-inflammatory properties without cytotoxicity. The present study also reported the chemical constituents of white mulberry fruit extracts, including some associated with observed biological activities of antioxidant and anti-inflammatory agents. Our findings indicate that white mulberry fruits have protective effects against oxidative stress and inflammatory responses, suggesting their nutraceutical and pharmaceutical potential to be developed as natural antioxidant and anti-inflammatory agents.

Author Contributions: Conceptualization, C.-I.C. and K.H.K.; formal analysis, J.S.Y., S.H.L., and S.R.L.; investigation, J.S.Y., S.H.L., and S.R.L.; writing-original draft preparation, C.-I.C. and K.H.K.; writing-review and editing, C.-I.C. and K.H.K.; supervision, C.-I.C. and K.H.K.; project administration, K.H.K.; funding acquisition, K.H.K. All authors have read and agreed to the published version of the manuscript.

Funding: This work was supported by a National Research Foundation of Korea (NRF) grant funded by the Korean government (MSIT) (2018R1A2B2006879 and 2019R1A5A2027340).

Institutional Review Board Statement: Not applicable.

Informed Consent Statement: Not applicable. 
Conflicts of Interest: The authors declare no conflict of interest.

Sample Availability: Samples of the compounds are not available from the authors.

\section{References}

1. Arulselvan, P.; Fard, M.T.; Tan, W.S.; Gothai, S.; Fakurazi, S.; Norhaizan, M.E.; Kumar, S.S. Role of Antioxidants and Natural Products in Inflammation. Oxid. Med. Cell. Longev. 2016, 2016, 1-15. [CrossRef]

2. Fialkow, L.; Wang, Y.; Downey, G.P. Reactive oxygen and nitrogen species as signaling molecules regulating neutrophil function. Free Radic. Biol. Med. 2007, 42, 153-164. [CrossRef] [PubMed]

3. Bartsch, H.; Nair, J. Chronic inflammation and oxidative stress in the genesis and perpetuation of cancer: role of lipid peroxidation, DNA damage, and repair. Langenbecks Arch. Surg. 2006, 391, 499-510. [CrossRef]

4. Prabhakar, O. Cerebroprotective effect of resveratrol through antioxidant and anti-inflammatory effects in diabetic rats. Naunyn. Schmiedebergs Arch. Pharmacol. 2013, 386, 705-710. [CrossRef]

5. Kang, H.-J.; Jeong, J.-S.; Park, N.-J.; Go, G.-B.; Kim, S.O.; Park, C.; Kim, B.W.; Hong, S.-H.; Choi, Y.H. An ethanol extract of Aster yomena (Kitam.) Honda inhibits lipopolysaccharide-induced inflammatory responses in murine RAW 264.7 macrophages. Biosci. Trends 2017, 11, 85-94. [CrossRef] [PubMed]

6. Afrin, S.; Gasparrini, M.; Forbes-Hernández, T.Y.; Cianciosi, D.; Reboredo-Rodriguez, P.; Manna, P.P.; Battino, M.; Giampieri, F. Protective effects of Manuka honey on LPS-treated RAW 264.7 macrophages. Part 1: Enhancement of cellular viability, regulation of cellular apoptosis and improvement of mitochondrial functionality. Food Chem. Toxicol. 2018, 121, 203-213. [CrossRef]

7. Gao, X.; Zhang, S.; Wang, L.; Yu, L.; Zhao, X.; Ni, H.; Wang, Y.; Wang, J.; Shan, C.; Fu, Y. Anti-Inflammatory Effects of Neochlorogenic Acid Extract from Mulberry Leaf (Morus alba L.) Against LPS-Stimulated Inflammatory Response through Mediating the AMPK/Nrf2 Signaling Pathway in A549 Cells. Molecules 2020, 25, 1385. [CrossRef] [PubMed]

8. Liu, Y.; Ji, D.; Turgeon, R.; Chen, J.; Lin, T.; Huang, J.; Luo, J.; Zhu, Y.; Zhang, C.; Lv, Z. Physiological and Proteomic Responses of Mulberry Trees (Morus alba. L.) to Combined Salt and Drought Stress. Int. J. Mol. Sci. 2019, 20, 2486. [CrossRef]

9. Ramappa, V.K.; Srivastava, D.; Singh, P.; Kumar, U.; Kumar, D.; Gosipatala, S.B.; Saha, S.; Kumar, D.; Raj, R. Mulberries: A Promising Fruit for Phytochemicals, Nutraceuticals, and Biological Activities. Int. J. Fruit Sci. 2020, 1-26. [CrossRef]

10. Dettmer, K.; Aronov, P.A.; Hammock, B.D. Mass spectrometry-based metabolomics. Mass Spectrom. Rev. 2007, 26, 51-78. [CrossRef]

11. Yu, J.S.; Lee, D.; Lee, S.R.; Lee, J.W.; Choi, C.-I.; Jang, T.S.; Kang, K.S.; Kim, K.H. Chemical characterization of cytotoxic indole acetic acid derivative from mulberry fruit (Morus alba L.) against human cervical cancer. Bioorganic Chem. 2018, 76, 28-36. [CrossRef]

12. Lee, S.R.; Park, J.Y.; Yu, J.S.; Lee, S.O.; Ryu, J.-Y.; Choi, S.-Z.; Kang, K.S.; Yamabe, N.; Kim, K.H. Odisolane, a novel oxolane derivative, and antiangiogenic constituents from the fruits of mulberry (Morus alba L.). J. Agric. Food Chem. 2016, 64, 3804-3809. [CrossRef] [PubMed]

13. Jung, S.; Lee, M.-S.; Choi, A.-J.; Kim, C.-T.; Kim, Y. Anti-Inflammatory effects of high hydrostatic pressure extract of mulberry (Morus alba) fruit on LPS-stimulated RAW264. 7 cells. Molecules 2019, 24, 1425. [CrossRef]

14. Kim, E.-O.; Yu, M.-H.; Lee, Y.-J.; Leem, H.-H.; Kim, S.; Kang, D.-H.; Choi, S.-W. Comparison of functional constituents and biological activity of the seed extracts from two mulberry fruits. Prev. Nutr. Food Sci. 2010, 15, 98-104. [CrossRef]

15. Kim, S.B.; Chang, B.Y.; Hwang, B.Y.; Kim, S.Y.; Lee, M.K. Pyrrole alkaloids from the fruits of Morus alba. Bioorg. Med. Chem. Lett. 2014, 24, 5656-5659. [CrossRef]

16. Chu, Q.; Lin, M.; Tian, X.; Ye, J. Study on capillary electrophoresis-amperometric detection profiles of different parts of Morus alba L. J. Chromatogr. A 2006, 1116, 286-290. [CrossRef] [PubMed]

17. Perez, J.L.; Jayaprakasha, G.K.; Patil, B.S. Metabolite profiling and in vitro biological activities of two commercial bitter melon (Momordica charantia Linn.) cultivars. Food Chem. 2019, 288, 178-186. [CrossRef] [PubMed]

18. Kim, M.-J.; Park, E.-J. Feature analysis of different in vitro antioxidant capacity assays and their application to fruit and vegetable samples. J. Korean Soc. Food Sci. Nutr. 2011, 40, 1053-1062. [CrossRef]

19. Molyneux, P. The use of the stable free radical diphenylpicrylhydrazyl (DPPH) for estimating antioxidant activity. Songklanakarin. J. Sci. Technol. 2004, 26, 211-219.

20. Awika, J.M.; Rooney, L.W.; Wu, X.; Prior, R.L.; Cisneros-Zevallos, L. Screening methods to measure antioxidant activity of sorghum (Sorghum bicolor) and sorghum products. J. Agric. Food Chem. 2003, 51, 6657-6662. [CrossRef]

21. Benzie, I.F.; Strain, J.J. The ferric reducing ability of plasma (FRAP) as a measure of "antioxidant power": the FRAP assay. Anal. Biochem. 1996, 239, 70-76. [CrossRef] [PubMed]

22. Wang, Y.; Xiang, L.; Wang, C.; Tang, C.; He, X. Antidiabetic and Antioxidant Effects and Phytochemicals of Mulberry Fruit (Morus Alba L.) Polyphenol Enhanced Extract. PLoS ONE 2013, 8, e71144. [CrossRef]

23. Finkel, T.; Holbrook, N.J. Oxidants, oxidative stress and the biology of ageing. Nature 2000, 408, 239-247. [CrossRef] [PubMed]

24. Wang, L.; Xu, M.L.; Liu, J.; Wang, Y.; Hu, J.H.; Wang, M.-H. Sonchus asper extract inhibits LPS-induced oxidative stress and pro-inflammatory cytokine production in RAW264. 7 macrophages. Nutr. Res. Pract. 2015, 9, 579-585. [CrossRef] [PubMed]

25. Seo, Y.-J.; Jeong, M.; Lee, K.-T.; Jang, D.S.; Choi, J.-H. Isocyperol, isolated from the rhizomes of Cyperus rotundus, inhibits LPS-induced inflammatory responses via suppression of the NF- $\mathrm{kB}$ and STAT3 pathways and ROS stress in LPS-stimulated RAW 264.7 cells. Int. Immunopharmacol. 2016, 38, 61-69. [CrossRef] [PubMed] 
26. Gasparrini, M.; Forbes-Hernandez, T.Y.; Giampieri, F.; Afrin, S.; Alvarez-Suarez, J.M.; Mazzoni, L.; Mezzetti, B.; Quiles, J.L.; Battino, M. Anti-inflammatory effect of strawberry extract against LPS-induced stress in RAW 264.7 macrophages. Food Chem. Toxicol. 2017, 102, 1-10. [CrossRef] [PubMed]

27. Oh, H.J.; Magar, T.B.T.; Pun, N.T.; Lee, Y.; Kim, E.H.; Lee, E.-S.; Park, P.-H. YJI-7 Suppresses ROS Production and Expression of Inflammatory Mediators via Modulation of p38MAPK and JNK Signaling in RAW 264.7 Macrophages. Biomol. Ther. 2018, 26, 191-200. [CrossRef]

28. Krishnamurthy, P.; Wadhwani, A. Antioxidant enzymes and human health. Antioxid. Enzyme 2012, 1, 3-18.

29. Powers, S.K.; Jackson, M.J. Exercise-induced oxidative stress: cellular mechanisms and impact on muscle force production. Physiol. Rev. 2008, 88, 1243-1276. [CrossRef]

30. Lee, S.E.; Ju, E.M.; Kim, J.H. Antioxidant activity of extracts from Euryale ferox seed. Exp. Mol. Med. 2002, 34, 100-106. [CrossRef]

31. Moncada, S.; Higgs, E.A. Molecular mechanisms and therapeutic strategies related to nitric oxide. FASEB J. 1995, 9, 1319-1330. [CrossRef] [PubMed]

32. Kiss, J.P.; Vizi, E.S. Nitric oxide: a novel link between synaptic and nonsynaptic transmission. Trends Neurosci. 2001, 24, 211-215. [CrossRef]

33. Förstermann, U.; Nakane, M.; Tracey, W.R.; Pollock, J.S. Isoforms of nitric oxide synthase: functions in the cardiovascular system. Eur. Heart J. 1993, 14, 10.

34. Boscá, L.; Zeini, M.; Través, P.G.; Hortelano, S. Nitric oxide and cell viability in inflammatory cells: a role for NO in macrophage function and fate. Toxicology 2005, 208, 249-258. [CrossRef] [PubMed]

35. Joo, T.; Sowndhararajan, K.; Hong, S.; Lee, J.; Park, S.-Y.; Kim, S.; Jhoo, J.-W. Inhibition of nitric oxide production in LPS-stimulated RAW 264.7 cells by stem bark of Ulmus pumila L. Saudi J. Biol. Sci. 2014, 21, 427-435. [CrossRef]

36. Lakhanpal, P.; Rai, D.K. Quercetin: A versatile flavonoid. Internet J. Med. Update 2007, 2, 22-37. [CrossRef]

37. López-Lázaro, M. Distribution and biological activities of the flavonoid luteolin. Mini Rev. Med. Chem. 2009, 9, 31-59. [CrossRef]

38. Calderon-Montano, J.M.; Burgos-Morón, E.; Pérez-Guerrero, C.; López-Lázaro, M. A review on the dietary flavonoid kaempferol. Mini Rev. Med. Chem. 2011, 11, 298-344. [CrossRef]

39. Riaz, A.; Rasul, A.; Hussain, G.; Zahoor, M.K.; Jabeen, F.; Subhani, Z.; Younis, T.; Ali, M.; Sarfraz, I.; Selamoglu, Z. Astragalin: A bioactive phytochemical with potential therapeutic activities. Adv. Pharmacol. Sci. 2018, 2018. [CrossRef]

40. Sunil, C.; Xu, B. An insight into the health-promoting effects of taxifolin (dihydroquercetin). Phytochemistry 2019, 166, 112066. [CrossRef] [PubMed]

41. Sharma, V.; Kumar, P.; Pathak, D. Biological importance of the indole nucleus in recent years: a comprehensive review. $J$. Heterocycl. Chem. 2010, 47, 491-502. [CrossRef]

42. Cheng, S.-Y.; Huang, K.-J.; Wang, S.-K.; Wen, Z.-H.; Chen, P.-W.; Duh, C.-Y. Antiviral and anti-inflammatory metabolites from the soft coral Sinularia capillosa. J. Nat. Prod. 2010, 73, 771-775. [CrossRef] [PubMed]

43. Yang, X.; Kang, M.-C.; Lee, K.-W.; Kang, S.-M.; Lee, W.-W.; Jeon, Y.-J. Antioxidant activity and cell protective effect of loliolide isolated from Sargassum ringgoldianum subsp. coreanum. Algae 2011, 26, 201. [CrossRef]

44. Machado, F.B.; Yamamoto, R.E.; Zanoli, K.; Nocchi, S.R.; Novello, C.R.; Schuquel, I.T.A.; Sakuragui, C.M.; Luftmann, H.; UedaNakamura, T.; Nakamura, C.V. Evaluation of the antiproliferative activity of the leaves from Arctium lappa by a bioassay-guided fractionation. Molecules 2012, 17, 1852-1859. [CrossRef]

45. Park, S.H.; Choi, E.; Kim, S.; Kim, D.S.; Kim, J.H.; Chang, S.; Choi, J.S.; Park, K.J.; Roh, K.-B.; Lee, J. Oxidative stress-protective and anti-melanogenic effects of loliolide and ethanol extract from fresh water green algae, Prasiola japonica. Int. J. Mol. Sci. 2018, 19, 2825. [CrossRef]

46. Park, S.H.; Kim, D.S.; Kim, S.; Lorz, L.R.; Choi, E.; Lim, H.Y.; Hossain, M.A.; Jang, S.; Choi, Y.I.; Park, K.J. Loliolide presents antiapoptosis and antiscratching effects in human keratinocytes. Int. J. Mol. Sci. 2019, 20, 651. [CrossRef]

47. Lee, S.-H.; Kwak, C.-H.; Lee, S.-K.; Ha, S.-H.; Park, J.; Chung, T.-W.; Ha, K.-T.; Suh, S.-J.; Chang, Y.-C.; Chang, H.W. Antiinflammatory effect of ascochlorin in LPS-stimulated RAW 264.7 macrophage cells is accompanied with the down-regulation of iNOS, COX-2 and proinflammatory cytokines through NF-кB, ERK1/2, and p38 signaling pathway. J. Cell. Biochem. 2016, 117, 978-987. [CrossRef] [PubMed]

48. Kim, Y.-W.; West, X.Z.; Byzova, T.V. Inflammation and oxidative stress in angiogenesis and vascular disease. J. Mol. Med. 2013, 91, 323-328. [CrossRef]

49. Lawrence, T.; Fong, C. The resolution of inflammation: Anti-inflammatory roles for NF-кB. Int. J. Biochem. Cell Biol. 2010, 42, 519-523. [CrossRef]

50. Hong, S.C.; Jeong, J.B.; Koo, J.S. Inhibitory effect of essential oil from Agastache rugosa against nitric oxide (NO) production induced by inducible nitric oxide synthase (iNOS) over-expression through NF-B and mitogen-activated protein kinase (MAPK) activation in lipopolysaccharide (LPS)-stimulated RAW264. 7 cells. J. Med. Plants Res. 2012, 6, 4494-4500.

51. Li, J.; Xu, L.; Sang, R.; Yu, Y.; Ge, B.; Zhang, X. Immunomodulatory and anti-inflammatory effects of total flavonoids of Astragalus by regulating NF-KB and MAPK signalling pathways in RAW 264.7 macrophages. Pharm. Int. J. Pharm. Sci. 2018, 73, 589-593.

52. Monmai, C.; Go, S.H.; Shin, I.; You, S.; Lee, H.; Kang, S.; Park, W.J. Immune Enhancement Effect of Asterias amurensis Fatty Acids through NF-kB and MAPK Pathways on RAW 264.7 Cells. J. Microbiol. Biotechnol. 2018, 28, 349-356. [CrossRef] [PubMed]

53. Dewanto, V.; Wu, X.; Adom, K.K.; Liu, R.H. Thermal processing enhances the nutritional value of tomatoes by increasing total antioxidant activity. J. Agric. Food Chem. 2002, 50, 3010-3014. [CrossRef] [PubMed] 
54. Zhishen, J.; Mengcheng, T.; Jianming, W. The determination of flavonoid contents in mulberry and their scavenging effects on superoxide radicals. Food Chem. 1999, 64, 555-559. [CrossRef]

55. Yang, E.-J.; Hyun, K.H.; Kim, H.; Kim, M.-J.; Lee, N.H.; Hyun, C.-G. Acanthopanax koreanum roots inhibit the expression of pro-inflammatory cytokines, inducible nitric oxide synthase, and cyclooxygenase-2 in RAW 264.7 macrophages. Orient. J. Chem. 2016, 32, 29-35. [CrossRef]

56. Lee, S.; Ryoo, R.; Choi, J.H.; Kim, J.-H.; Kim, S.-H.; Kim, K.H. Trichothecene and tremulane sesquiterpenes from a hallucinogenic mushroom Gymnopilus junonius and their cytotoxicity. Arch. Pharm. Res. 2020, 43, 214-223. [CrossRef]

57. Trinh, T.A.; Park, E.J.; Lee, D.; Song, J.H.; Lee, H.L.; Kim, K.H.; Kim, Y.; Kung, K.; Kang, K.S.; Yoo, J.E. Estrogenic Activity of Sanguiin H-6 through Activation of Estrogen Receptor Î \pm Coactivator-binding Site. Nat. Prod. Sci. 2019, 25, 28-33. [CrossRef]

58. Lee, S.R.; Kang, H.; Yoo, M.J.; Yu, J.S.; Lee, S.; Yi, S.A.; Beemelmanns, C.; Lee, J.; Kim, K.H. Anti-adipogenic pregnane steroid from a Hydractinia-associated fungus, Cladosporium sphaerospermum SW67. Nat. Prod. Sci. 2020, 26, 230-235.

59. Lee, K.; Seo, Y.-J.; Song, J.-H.; Chei, S.; Lee, B.-Y. Ginsenoside Rg1 promotes browning by inducing UCP1 expression and mitochondrial activity in 3T3-L1 and subcutaneous white adipocytes. J. Ginseng Res. 2019, 43, 589-599. [CrossRef]

60. Blois, M.S. Antioxidant determinations by the use of a stable free radical. Nature 1958, 181, 1199-1200. [CrossRef]

61. Arts, M.J.; Haenen, G.R.; Voss, H.-P.; Bast, A. Antioxidant capacity of reaction products limits the applicability of the Trolox Equivalent Antioxidant Capacity (TEAC) assay. Food Chem. Toxicol. 2004, 42, 45-49. [CrossRef] [PubMed]

62. Sittisart, P.; Chitsomboon, B. Intracellular ROS Scavenging Activity and Downregulation of Inflammatory Mediators in RAW264.7 Macrophage by Fresh Leaf Extracts of Pseuderanthemum palatiferum. Evid. Based Complement. Alternat. Med. 2014, $2014,1-11$. [CrossRef] [PubMed]

63. Jo, M.S.; Lee, S.; Yu, J.S.; Baek, S.C.; Cho, Y.-C.; Kim, K.H. Megastigmane Derivatives from the Cladodes of Opuntia humifusa and Their Nitric Oxide Inhibitory Activities in Macrophages. J. Nat. Prod. 2020, 83, 684-692. [CrossRef] [PubMed] 